\title{
Purification and characterization of plantaricin A, a Lactobacillus plantarum bacteriocin whose activity depends on the action of two peptides
}

\author{
Jon Nissen-Meyer, ${ }^{1}$ Anette Granly Larsen, ${ }^{2}$ Knut Sletten,,$^{3}$ Mark Daeschel ${ }^{4}$ \\ and INGOLF F. Nes ${ }^{1 *}$ \\ ${ }^{1}$ Laboratory of Microbial Gene Technology, PO Box 5051, NFR, Agricultural University of Norway, N-1432 As, \\ Norway \\ ${ }^{2}$ Department of Dairy and Food Science, The Royal Veterinary and Agricultural University, Copenhagen, Denmark \\ ${ }^{3}$ Department of Biochemistry, University of Oslo, Norway \\ ${ }^{4}$ Department of Food Science and Technology, Oregon State University, Corvallis, Oregon, USA
}

(Received 7 January 1993; revised 16 March 1993; accepted 24 March 1993)

\begin{abstract}
A Lactobacillus plantarum bacteriocin, plantaricin $\mathbf{A}$, has been purified to homogeneity by ammonium sulphate precipitation, binding to cation exchanger and Octyl-Sepharose, and reverse-phase chromatography. The bacteriocin activity was associated with two peptides, termed $\alpha$ and $\beta$, which were separated upon reverse-phase chromatography. Bacteriocin activity required the complementary action of both the $\alpha$ and $\beta$ peptides. From the $\mathrm{N}$-terminal end, 21 and 22 amino acid residues of $\alpha$ and $\beta$, respectively, were sequenced. Further attempts at sequencing revealed no additional amino acid residues, suggesting that either the $C$ terminus had been reached or that modifications in the next amino acid residue blocked the sequencing reaction. Judging from their amino acid sequence, $\alpha$ and $\beta$ may be encoded by the same gene, since $\alpha$ appeared to be a truncated form of $\beta$. Alanine, the first amino acid residue at the $N$-terminal end of $\beta$ was not present at this position in $\alpha$. Otherwise the sequences of $\alpha$ and $\beta$ appeared to be identical. The calculated molecular masses of the sequenced part of $\alpha$ and $\beta$ were 2426 and 2497 Da, respectively. The molecular masses of $\alpha$ and $\beta$ as determined by mass spectroscopy were $2687 \pm 30$ and $2758 \pm 30 \mathrm{Da}$, respectively, indicating that (i) the only difference between $\alpha$ and $\beta$ was the presence of the $N$ terminal alanine residue in $\beta$, and that (ii) in addition to the sequenced residues, two to three unidentified amino acid residues are present at the $C$-terminal ends of the $\alpha$ and $\beta$ peptides. Both $\alpha$ and $\beta$ may form amphiphilic $\alpha$ helices, suggesting that they are pore-forming peptides that create cell membrane channels through a 'barrel-stave' mechanism.
\end{abstract}

\section{Introduction}

Bacteriocins are proteinaceous compounds that show bactericidal activity, often towards bacteria that are closely related to the bacteriocin-producing species (Tagg et al., 1976). Due to their potential use as antibacterial agents, bacteriocins have been the subject of much interest. A number of bacteriocins produced by lactic acid bacteria have been described (Klaenhammer, 1988).

*Author for correspondence. Tel. 4764949471 ; fax 4764941465 ; email BIOIFN@NLH10.NLH.NO.

The amino acid sequence data reported in this paper have been submitted to EMBL and assigned the accession number P80214.
Recently, the complete or partial primary structure has been elucidated for some of these bacteriocins. Based on their structure they may be divided into two groups. The first, termed the lantibiotic group, comprises bacteriocins consisting of one polypeptide chain that has been posttranslationally modified, the modified amino acids being lanthionine and methyllanthionine as well as their precursors, dehydroalanine and dehydrobutyrine. This group contains nisin A (Buchman et al., 1988; Dodd et al., 1990; Gross \& Morell, 1971; Hurst, 1981; Kaletta \& Entian, 1989), nisin Z (Mulders et al, 1991), lactocin S (Mørtvedt et al., 1991), carnocin U149 (Stoffels et al., 1992) and lacticin 481 (Piard et al., 1992).

The second group comprises bacteriocins with no modification in their polypeptide. This group contains 
curvacin A, sakacin P (Tichaczek et al., 1992), pediocin PA-1 (Henderson et al., 1992; Nieto Lozano et al., 1992), leucocin A-UAL 187 (Hastings et al., 1991), lactococcin A (Holo et al., 1991; Van Belkum et al., 1991), and probably lactacin $F$ (Muriana \& Klaenhammer, 1991 a,b) and helveticin J (Joerger \& Klaenhammer, 1990). The first four of the abovementioned bacteriocins form a subgroup within the group of bacteriocins that consist of one unmodified peptide chain, as these four have a similar amino acid sequence (Nieto Lozano et al., 1992). The second group also contains bacteriocins that require two different peptides to exert bactericidal activity. As yet only one bacteriocin of this kind has been identified (NissenMeyer et al., 1992). This bacteriocin, termed lactococcin G, requires the complementary action of two entirely different peptides to exert bactericidal activity (NissenMeyer et al., 1992). The N-terminal half of both of these peptides may form an amphiphilic $\alpha$-helix, indicating that the peptides are pore-forming toxins (Nissen-Meyer et al., 1992).

This study describes a novel bacteriocin, termed plantaricin A. Plantaricin A is produced by $L$, plantarum $\mathrm{C}-11$, and in crude preparations the bacteriocin is heat stable, non-dialysable and active over the range pH 4.0-6.5 (Daeschel et al., 1990). It has bactericidal activity towards some species of four genera of lactic acid bacteria, but not towards other Gram-positive or Gramnegative bacteria, or yeast (Daeschel et al., 1990). The observed spectrum of activity is intermediate in breadth as compared to the narrow spectrum of lactacin B (Barefoot \& Klaenhammer, 1983), lactacin F (Muriana \& Klaenhammer, 1987), helveticin J (Joerger \& Klaenhammer, 1990) and casecin 80 (Rammelsberg \& Radler, 1990), and the broad spectrum of nisin (Buchman et al., 1988) and pediocin A (Daeschel et al., 1985).

\section{Methods}

Bacterial strains and media. The bacteriocin producer was Lactobacillus plantarum C-11 (Daeschel et al., 1990) and the indicator organism used in the bacteriocin assay was L. plantarum 965 (Daeschel et al., 1990). Both strains were grown at $30^{\circ} \mathrm{C}$ in MRS broth (Oxoid).

Bacteriocin assay. The bacteriocin was quantified in a microtitre plate assay system. Each well of the microtitre plate contained $200 \mu \mathrm{l}$ MRS broth, bacteriocin fractions at twofold dilutions and the indicator organism $\left(\mathrm{OD}_{600}=0 \cdot 1\right)$. The microtitre plate cultures were incubated for about $6 \mathrm{~h}$ at $30^{\circ} \mathrm{C}$, after which growth inhibition of the indicator organism was measured spectrophotometrically at $600 \mathrm{~nm}$ using a Dynatech Microplate Reader. One bacteriocin unit (BU) was defined as the amount of bacteriocin that inhibited growth of the indicator organism by $50 \%$ ( $50 \%$ of the turbidity of the control culture without bacteriocin).

Bacteriocin purification. The bacteriocin was purified from 1-2 litre cultures of $L$. plantarum $\mathrm{C}-11$ as described for lactococcin G (NissenMeyer et al., 1992). The cultures were grown to early stationary phase.
The cells were then removed by centrifugation at $4000 \mathrm{~g}$ for $15 \mathrm{~min}$ at $4{ }^{\circ} \mathrm{C}$, and $300 \mathrm{~g}$ ammonium sulphate per litre of culture supernatant was added. The protein precipitate was pelleted by centrifugation at $7000 \mathrm{~g}$ for $20 \mathrm{~min}$ and solubilized in $20 \mathrm{~mm}$-sodium phosphate buffer, pH 7 (buffer A; $200 \mathrm{ml}$ per 1.5 culture) (fraction I). Fraction I was applied at a flow rate of about $10 \mathrm{ml} \mathrm{min}{ }^{-1}$ to a $7 \mathrm{ml} \mathrm{S}$-Sepharose Fast Flow cation exchange column equilibrated with buffer $A$. After subsequent washing of the column with $20 \mathrm{ml}$ buffer $\mathrm{A}$, the bacteriocin was eluted from the column with $40 \mathrm{ml} 1 \mathrm{M}-\mathrm{NaCl}$ in buffer $\mathrm{A}$ (fraction II). Ammonium sulphate was added to fraction II to a final concentration of $10 \%(\mathrm{w} / \mathrm{v})$, after which the fraction was applied at a flow rate of about $4 \mathrm{ml} \mathrm{min}{ }^{-1}$ to a $2 \mathrm{ml} \mathrm{Octyl-Sepharose} \mathrm{CL-4B} \mathrm{column}$ equilibrated with $10 \%(\mathrm{w} / \mathrm{v})$ ammonium sulphate in buffer $\mathrm{A}$. The column was then washed with $8 \mathrm{ml}$ buffer $\mathrm{A}$, after which the bacteriocin activity was eluted from the column with $10 \mathrm{ml} 70 \%(\mathrm{v} / \mathrm{v})$ ethanol and $30 \%$ buffer A (fraction III). Fraction III was diluted to $50 \mathrm{ml}$ with water containing $0 \cdot 1 \%(\mathrm{v} / \mathrm{v})$ trifluoroacetic acid (TFA) and subsequently applied to a $\mathrm{C}_{2} / \mathrm{C}_{18}$ reverse-phase column, PepRPC HR 5/5, equilibrated with 2-propanol/water $(10: 90, \mathrm{v} / \mathrm{v})$, containing $0.1 \%$ TFA. The bacteriocin was eluted with a linear gradient ranging from 30 to $40 \% 2$-propanol containing $0.1 \%$ TFA (fraction IV). The bacteriocin peptides eluting from the reverse-phase column (fraction IV) were diluted four- to fivefold with water containing $0 \cdot 1 \%$ TFA and rechromatographed on the reverse-phase column. Purified bacteriocin was stored in 50-60\% 2-propanol and/or ethanol containing $0.1 \%$ TFA at $-20{ }^{\circ} \mathrm{C}$.

Amino acid sequencing and mass spectroscopy analysis. Amino acid sequencing and mass spectroscopy was performed as described previously (Nissen-Meyer et al., 1992).

\section{Results and Discussion}

\section{Purification of bacteriocin}

The bacteriocin was isolated from cultures in stationary phase, as maximum activity was found in the culture medium during this growth phase. The bacteriocin was purified by ammonium sulphate precipitation, binding to a cation exchanger and then to Octyl-Sepharose before the final reverse-phase chromatography purification steps (Table 1). This resulted in a 1300 -fold increase in specific activity and a recovery of about $5 \%$ of the activity (Table 1, fraction III).

\section{Bacteriocin activity depends on the complementary action of two peptides}

When fraction III was applied to the reverse-phase column, one major bacteriocin activity peak (fraction 6 , Fig. 1) and several absorbance peaks eluted from the column (Fig. 1). In addition, a minor bacteriocin activity peak (fraction 4, Fig. 1) was often observed (in two out of four experiments) eluting slightly ahead of the major activity peak. Judging from the absorbance profile (Fig. 1), two components were present in fraction 6 , and these could be separated from each other upon rechromatography on the reverse-phase column (Fig. 2). They were termed $\alpha$ and $\beta, \alpha$ being the first of the two to elute from the column. Very little bacteriocin activity was associated 
Table 1. Purification of plantaricin A

\begin{tabular}{lrrrrrr}
\hline \hline Fraction & $\begin{array}{c}\text { Volume } \\
(\mathrm{ml})\end{array}$ & $\begin{array}{r}\text { Total } \\
A_{280}{ }^{*}\end{array}$ & $\begin{array}{c}\text { Total } \\
\text { activity } \\
(\mathbf{B U})\end{array}$ & $\begin{array}{c}\text { Specific } \\
\text { activity }\end{array}$ & $\begin{array}{c}\text { Increase } \\
\text { in specific } \\
\text { activity }\end{array}$ & $\begin{array}{c}\text { Yield } \\
(\%)\end{array}$ \\
\hline $\begin{array}{l}\text { Culture supernatant } \\
\text { Ammonium sulphate } \\
\text { precipitation (fraction I) }\end{array}$ & 1500 & 74000 & $10 \times 10^{6}$ & 135 & 1 & 100 \\
$\begin{array}{c}\text { Binding to cation } \\
\text { exchanger (fraction II) } \\
\text { Binding to Octyl- } \\
\text { Sepharose (fraction III) }\end{array}$ & 10 & 1900 & $3.5 \times 10^{6}$ & 1840 & 14 & 35 \\
\hline \hline
\end{tabular}

* Total $A_{280}$ is $A_{280} \times$ volume (ml).

$\dagger$ Specific activity is total activity/total $A_{280}$.

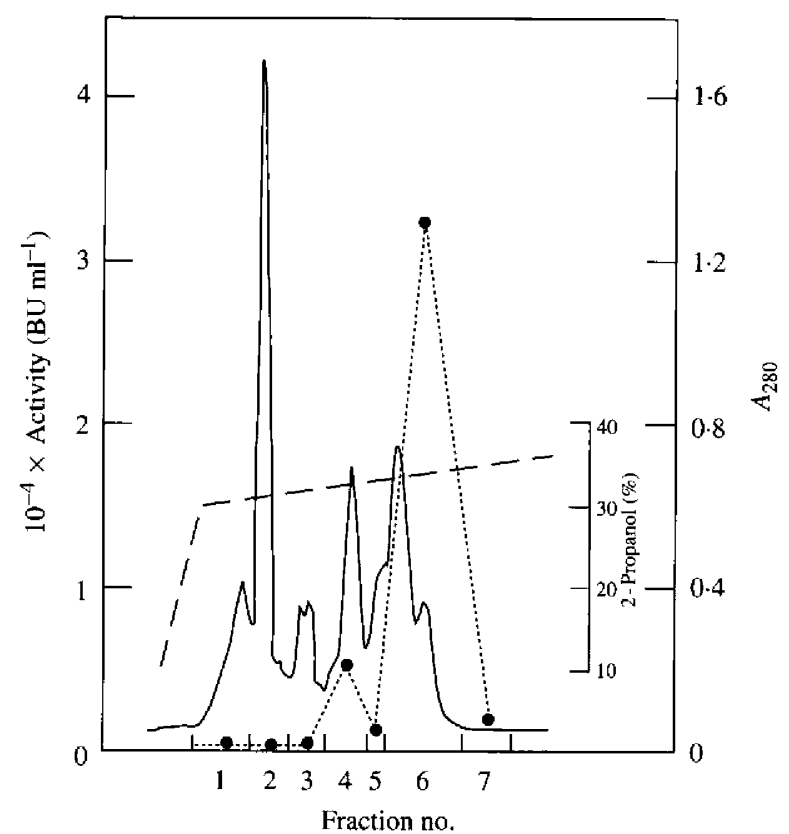

Fig. 1. Reverse-phase chromatography of plantaricin A (fraction III). The amount applied to the column was obtained from approximately 2 litres of culture. $-\cdots$. , Bacteriocin activity;,$- A_{280} ;--, 2-$ propanol gradient.

with either $\alpha$ and $\beta$ when they were assayed separately for bacteriocin activity (Fig. 2). However, bacteriocin activity was recovered upon adding $\beta$ to the column fractions containing $\alpha$ (Fig. $2 a$ ), or $\alpha$ to the column fractions containing $\beta$ (Fig. $2 b$ ). No significant additional increase in bacteriocin activity was seen upon adding an aliquot of the other column fractions shown in Fig. 1 (fractions 1-5, Fig. 1) to fractions containing both $\beta$ and $\alpha$ (data not shown). Thus the complementary action of two peptides, an $\alpha$ and a $\beta$ peptide, was necessary to obtain bacteriocin activity. The purified $\alpha$ and $\beta$ bacteriocin activity appeared unstable during reversephase chromatography, since much of the activity was lost in this last purification step. The final recovery of activity after the last reverse phase chromatography purification step was in the range $0 \cdot 1-1 \%$.

\section{Amino acid sequence and mass spectroscopy}

The $\mathrm{N}$-terminal amino acid sequences of $\alpha$ and $\beta$ peptides are shown in Fig. 3. It appears that $\alpha$ is identical to $\beta$ except that an alanine residue is found as the first and as an additional amino acid residue at the $\mathrm{N}$-terminal end of $\beta$. Otherwise the amino acid sequences of the two peptides are identical. Therefore, it is likely that $\alpha$ and $\beta$ are encoded by the same gene, and that $\alpha$ is processed into a truncated form of $\beta$ by post-translational cleavage. From the $\mathrm{N}$-terminal end, 21 and 22 amino acid residues of $\alpha$ and $\beta$, respectively, were sequenced. Additional amino acid residues were not detected upon attempting further sequencing, suggesting either that the C-terminal end was reached or that modifications in the next amino acid residue blocked the sequence reaction. The calculated molecular masses of the sequenced part of $\alpha$ and $\beta$ (Fig. 3) were 2426 and $2497 \mathrm{Da}$, respectively, whereas the molecular masses of $\alpha$ and $\beta$ as determined by plasma disorption mass spectrometry were $2687 \pm 30$ and $2758 \pm 30 \mathrm{Da}$, respectively, indicating that in addition to the sequenced amino acid residues shown in Fig. 3, 2-3 unidentified residues are present at the C-terminal ends of the $\alpha$ and $\beta$ peptides. It is very unlikely that plantaricin $\mathrm{A}$ is a lantibiotic and contains dehydrated forms of serine or threonine which have been shown to block amino acid sequencing by Edman degradation. Amino acid composition analysis of plantaricin A has not revealed any lanthionines (data not shown). Furthermore, plantaricin A contains serine and threonine which are commonly modified to didehydroalanine and didehydrobutyrine in lantibiotics. Consequently, some unknown modification on the plantaricin A causes the blocking of amino acid sequencing. The molecular masses determined by mass spectroscopy also suggest that the only difference between $\alpha$ and $\beta$ was the presence 


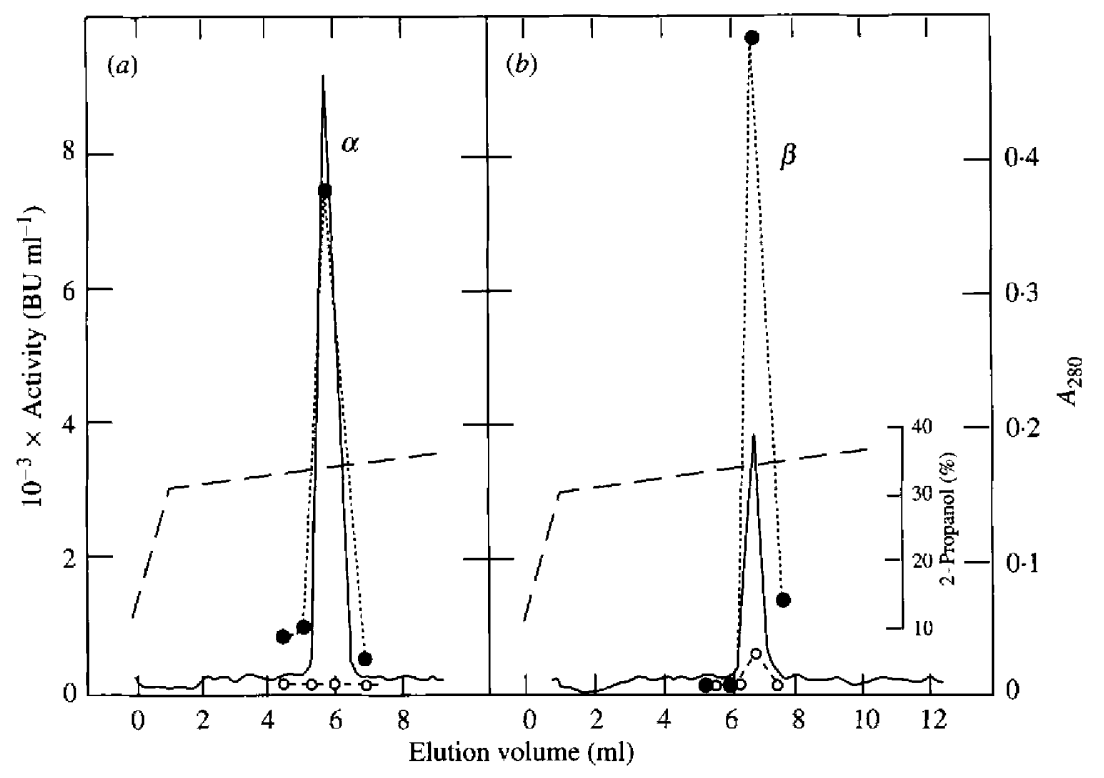

Fig. 2. Reverse-phase chromatography of $(a) \propto$ and $(b) \beta$. The bacteriocin activity without $\left(\mathrm{O}^{--} \mathrm{O}\right)$ and with complementation $(\cdots \cdots)$ with $(a) \beta$ or with $(b) \alpha$. The amount applied to the column was obtained from approximately 2 litres of culture.,$- A_{280} ;--$, 2-propanol gradient.

1

5

10

15

20

$\alpha \quad$ N Tyr Ser Leu Gin Met Gly Ala Thr Ala lle Lys Gin Val Lys Lys Leu Phe Lys Lys (Trp) Gly
$\beta$ N Ala Tyr Ser Leu GI
1
5
10
1520

Fig. 3. N-terminal amino acid sequence of $\alpha$ and $\beta$. Uncertain amino acids are in parentheses. $N$ indicates the $N$-terminal end of the peptide.

of the N-terminal alanine residue in $\beta$. It is surprising that this small difference is enough to enable the two peptides to complement each other such that bacteriocin activity may be detected in the presence of both peptides, but not when only one of the peptides is present.

The amino acid sequence of $\alpha$ and $\beta$ suggests that these peptides may be pore-forming toxins that create cell membrane channels through a 'barrel-stave' mechanism (Ojcius \& Young, 1991). The region in $\alpha$ starting with amino acid residue 3 and ending with residue 20 , and the corresponding region in $\beta$ starting with residue 4 and ending with 21 , may form an amphiphilic $\alpha$-helix. This is evident when the amino acid sequence in this region is displayed on an Edmundson $\alpha$-helical wheel (Fig. 4; Schiffer \& Edmundson, 1967). The non-polar residues are found almost completely on one side of the helix and the polar residues on the other side, the only exception being alanine (residue 7) which appears on the hydrophilic side. However, the substitution of one amino acid by one of opposite hydrophobicity may not cause a major disruption of the amphiphilic character of the peptide (Ojcius \& Young, 1991). Glycine (residue 6), which appears on the hydrophobic side (Fig. 4), is relatively neutral with respect to its hydrophobic/ hydrophilic character.

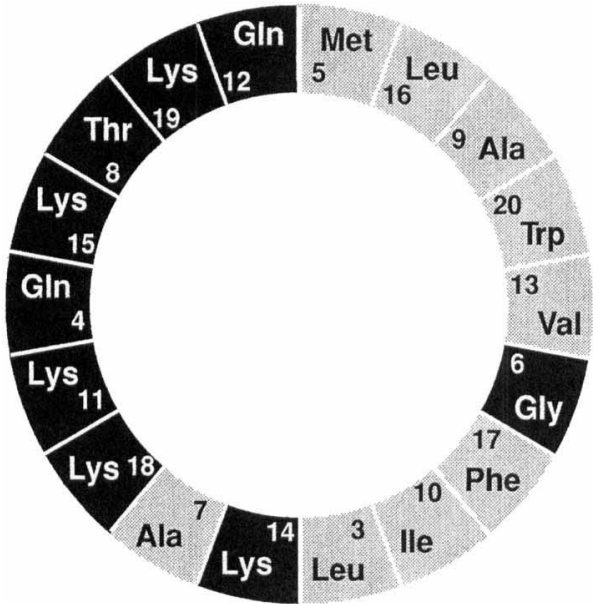

Fig. 4. Edmundson $\alpha$-helical wheel representation of the amphiphilical region in $\alpha$. The amphiphilical region shown starts with residue 3 and ends with residue 20 . The shaded areas indicate non-polar residues. An identical $\alpha$-helical wheel may be constructed for $\beta$, starting with amino acid residue 4 and ending with residue 21 .

The amphiphilic region in the $\alpha$ and $\beta$ peptides may allow the peptides to oligomerize into membranespanning pores such that the polar side of the helix faces towards the centre of the pore and the non-polar side faces the membrane-lipids (Lear et al., 1988; Ojcius \& 


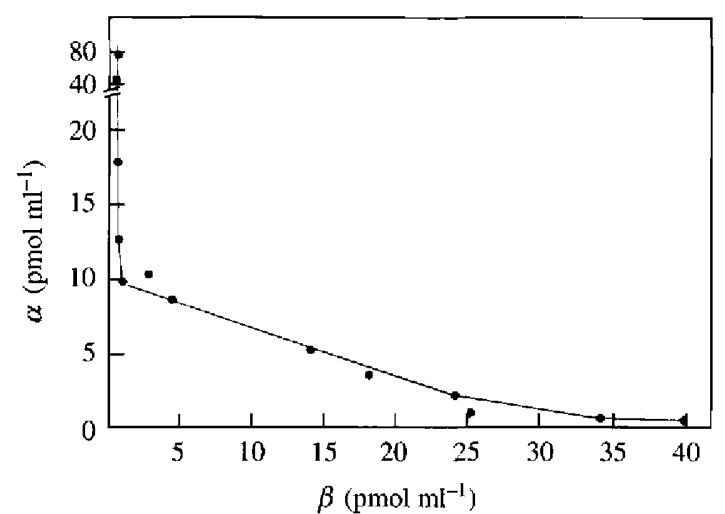

Fig. 5. The amounts of $\alpha$ and $\beta$ which in combination inhibited growth of the indicator strain by $50 \%$.

Young, 1991). An amphiphilic region is also found in the $\mathrm{N}$-terminal half of the $\alpha$ and $\beta$ peptides of lactococcin $\mathrm{G}$, a bacteriocin produced by Lactococcus lactis (NissenMeyer et al., 1992). Unlike plantaricin A, the two peptides of lactococcin $G$ are entirely different from each other (Nissen-Meyer et al., 1992). An amphiphilic distribution (although not so marked as in the peptides of plantaricin A and lactococcin $\mathrm{G}$ ) may also be detected in other lactic acid bacteria-produced bacteriocins, such as lactocin S (Mørtvedt et al., 1991) and lactococcin A (Holo et al., 1991). There is good evidence that the latter bacteriocin acts in fact by permeabilizing target cell membranes (Van Belkum et al., 1992), as also appears to be the case for nisin (Sahl et al., 1987).

A comparison of plantaricin $\mathrm{A}$ amino acid sequence to other known LAB bacteriocins did not reveal any significant homology (data not shown).

No meaningful amino acid sequence was obtained when the minor bacteriocin activity peak (fraction 4 , Fig. 1) was rechromatographed on the reverse-phase column and subsequently sequenced. Moreover, the bacteriocin activity was greatly reduced upon rechromatography of this fraction. One cannot exclude that the minor activity peak is a further breakdown product of the $\beta$ peptide. However, this minor peak of activity could also be due to some kind of inactivation of the peptide (not degradation) as seen also with lactococcin $\mathrm{G}$ (Nissen-Meyer et al., 1992).

\section{Relative amounts of $\alpha$ and $\beta$ necessary to obtain bacteriocin activity}

The concentrations of $\alpha$ and $\beta$, which in combination inhibited growth of the indicator organism by $50 \%$, are presented as an isobologram in Fig. 5. When $\alpha$ was in excess $\left(>10 \mathrm{pmol} \mathrm{ml}^{-1}\right.$ ), the presence of $\beta$ at a concentration of $1.0-0.2 \mathrm{pmol} \mathrm{m}^{-1}$ resulted in $50 \%$ growth inhibition (Fig. 5). Similarly, with an excess of $\beta$ $\left(>25 \mathrm{pmol} \mathrm{m}^{-1}\right)$, the presence of $\alpha$ at a concentration of $1 \cdot 0-0.4 \mathrm{pmol}$ resulted in a $50 \%$ growth inhibition (Fig. 5). Thus, about the same amounts of $\alpha$ and $\beta$ was needed to obtain $50 \%$ growth inhibition in the presence of an excess of the complementary peptide.

To our knowledge, lactococcin $\mathrm{G}$ represents the only other known bacteriocin whose activity depends on the complementary action of two peptides (Nissen-Meyer $e t$ al., 1992). However, whereas the $\alpha$ and $\beta$ peptides of lactococcin $\mathrm{G}$ are entirely different from each other with respect to their primary structure (Nissen-Meyer $e t$ al., 1992), plantaricin $A$ is novel as its $\alpha$ and $\beta$ peptides appear only to differ from each other in that $\beta$ contains an additional alanine residue at its $\mathrm{N}$-terminal end. Plantaricin A should represent an interesting model to study how two so similar peptides may complement each other to induce a bactericidal effect.

We are grateful to J. Thomsen, Department of Structural Biology, Novo Nordisk A/S, Denmark, for the use of the Biolon Mass Analyser, and to S. Bayne, Applied Biosystem Division of KEBO Lab Ballerup, Denmark, for analysing peptide samples on the Biolon Mass Analyser. This study has in part been supported by grant $P 89047$ from the Nordic Fund for Technology and Industrial Developments.

\section{References}

Barefoot, S. F. \& Klaenhammer, T. R. (1983). Detection and activity of lactacin B, a bacteriocin produced by Lactobacillus acidophilus. Applied and Environmental Microbiology 45, 1808-1815.

Buchman, G. W., Banerjee, S. \& Hansen, J. N. (1988). Structure, expression, and evolution of a gene encoding the precursor of nisin, a small protein antibiotic. Journal of Biological Chemistry 263, $16260-16266$

Daeschel, M. A., MCKenney, M. C. \& McDonald, L. C. (1985). Association of a 13.6-Megadalton plasmid in Pediococcus pentosaceus with bacteriocin activity. Applied and Environmental Microbiology 50, 1538 .

Daeschel, M. A., McKenney, M. C. \& McDonald, L. C. (1990). Bacteriocidal activity of Lactobacillus plantarum C-11. Food Microbiology 7, 91-99.

Dodd, H. M., Horn, N. \& Gasson, M. J. (1990). Analysis of the genetic determinant for production of the peptide antibiotic nisin. Journal of General Microbiology 136, 555-566.

Gross, E. \& MORELL, J. (1971). The structure of nisin. Journal of the American Chemical Society 93, 46344635.

Hastings, J. W., Sailer, M., Johnson, K., Roy, K. L., Vederas, J. C. \& STILES, M. (1991). Characterization of leucocin A-UAL 187 and cloning of the bacteriocin gene from Leuconostoc gelidum. Journal of Bacteriology 173, 7491-7500.

Henderson, J. T., Chopko, A. L. \& van Wassenaar, P. D. (1992) Purification and primary structure of pediocin PA-l produced by Pediococcus acidilactici PAC-1.0. Archives of Biochemistry and Biophysics 295, 5-12.

Holo, H., Nilssen, Ø. \& Nes, I. F. (1991). Lactococcin A, a new bacteriocin from Lactococcus lactis subsp. cremoris: isolation and characterization of the protein and its gene. Journal of Bacteriology 173, 3879-3887.

HuRst, A. (1981). Nisin. Advances in Applied Microbiology 27, 85-123. Jolrger, M. C. \& Klaenhammer, T. R. (1990). Cloning, expression, and nucleotide sequence of the Lactobacillus helveticus 481 gene encoding the bacteriocin helveticin J. Journal of Bacteriology 172, $6339-6347$.

Kaletta, C. \& Entian, K. D. (1989). Nisin, a peptide antibiotic: cloning and sequencing of the nis $A$ gene and posttranslational 
processing of its peptide product. Journal of Bacteriology 171, 1597-1601.

Klaenhammer, T. R. (1988). Bacteriocins of lactic acid bacteria. Biochimie 70, 337-349.

Lear, J. D., Wasserman, Z. \& DeGrado, W. F. (1988). Synthetic amphiphilic peptide models for protein ion channels. Science $\mathbf{2 4 0}$, $1177-1181$.

Mørtvedt, C. 1., Nissen-Meyer, J. \& Nes, I. F. (1991). Purification and amino acid sequence of lactocin $\mathrm{S}$, a bacteriocin produced by Lactobacillus sake L45. Applied and Environmental Microbiology 57, 1829-1834.

Mulders, J. W. M., Boerrigter, I. J., Rollema, H. S., Siezen, R. J. \& DE Vos, W. M. (1991). Identification and characterization of the lantibiotic nisin Z, a natural nisin variant. European Journal of Biochemistry 201, 581-584.

Muriana, P. M. \& Klaenhammer, T. R. (1987). Conjugal transfer of plasmid-encoded determinants for bacteriocin production and immunity in Lactobacillus acidophilus 88. Applied and Environmental Microbiology 53, 553-560.

Muriana, P. M. \& Klafnhammer, T. R. (1991a). Cloning, phenotypic expression, and DNA sequence of the gene for lactacin $F$, an antimicrobial peptide produced by Lactobacillus spp. Journal of Bacteriology 173, 1779-1788.

Muriana, P. M. \& Klaenhammer, T. R. (1991b). Purification and partial characterization of lactacin $F$, a bacteriocin produced by Lactobacillus acidophilus 11088 . Applied and Environmental Microbiology 57, 114-121.

Nieto Lozano, J. C., Nissen-Meyer, J., Sletten, K. \& Nes, I. F. (1992). Purification and amino acid sequence of a bacteriocin produced by Pediococcus acidilactici. Journal of General Microbiology 138, 1985-1990.

Nissin-Meyer, J., Holo, H., HÅvarstein, L. S., Sletten, K. \& Nes, I. F. (1992). A novel lactococcal bacteriocin whose activity depends on the complementary action of two peptides. Journal of Bacteriology 174, $5686-5692$.
Orcius, D. M. \& YounG, J. D.-E. (1991). Cytolytic pore-forming proteins and peptides: is there a common structural motif? Trends in Biochemical Sciences 16, 225-229.

Piard, J.-C., Muriana, P. M., Desmazeaud, M. J. \& Klaenhammer, T. R. (1992). Purification and partial characterization of lacticin 481, a lanthionine-containing bacteriocin produced by Lactococcus lactis subsp. CNRZ 481. Applied and Environmental Microbiology 58, 279-284.

Rammelseerg, M. \& RadLer, F. (1990). Antibacterial polypeptides of Lactobacillus species. Journal of Applied Bacteriology 69, 177-184.

Sahl, H.-G., Kordel, M. \& BeNz, R. (1987). Voltage-dependent depolarization of bacterial membranes and artificial lipid bilayers by the peptide antibiotic nisin. Archives of Microbiology 149, 120-124.

SchIFFER, M. \& Edmundson, A. B. (1967). Use of helical wheels to represent the structures of proteins and to identify segments with helical potential. Biophysical Journal 7, 121-135.

Stoffels, G., Nissen-Meyer, J., Gudmundsdottir, A., Sletten, K., HoLo, H. \& NEs, I. F. (1992). Purification and characterization of a new bacteriocin isolated from a Carnobacterium sp. Applied and Environmental Microbiology 58, 1417-1422.

TAGG, J. R., Dajani, A. S. \& Wannamaker, L. W. (1976). Bacteriocins of Gram-positive bacteria. Bacteriological Reviews 40, 722-756.

Tichaczek, P. S., Nissen-Meyer, J., Nes, I. F., Vogel, R. F. \& HAMmEs, W. P. (1992). Characterization of the bacteriocins curvacin $\mathbf{A}$ and sakacin $\mathbf{P}$ produced by Lactobacillus curvatus LTH1174 and L. sake LTH673. Systematic and Applied Microbiology $15,460-465$.

Van Belkum, M. J., Hayema, B. J., Jeeninga, R. E., KoK, J. \& VENEMA, G. (1991). Organization and nucleotide sequences of two lactococcal bacteriocin operons. Applied and Environmental Microbiology 57, 492-498.

Van Belkum, M. J., KoK, J., Venema, G., Holo, H., Nes, I. F., Konings, W. N. \& ABEe, T. (1992). The bacteriocin lactococcin A specifically increases the permeability of lactococcal cytoplasmic membranes in a voltage-independent, protein-mediated manner. Journal of Bacteriology 173, 7934-7941. 